\title{
NEGOCIAR LA PAZ EN CUBA (1896-1897)
}

\author{
POR \\ CRISTÓBAL ROBLES MUÑOZ \\ Departamento Historia Contemporánea. Centro de Estudios Históricos, CSIC.
}

Un año después de la sublevación de Baire, en marzo de 1896, existía una corriente patriótica, consciente de lo que entrañaba para España su permanencia en Cuba. Hubo iniciativas y ayudas para asegurar la victoria sobre los insurgentes. Los españoles residentes en México promovieron una suscripción para incrementar el poder de la armada. Se dirigieron a todos sus compatriotas en los países de América del Sur. Era una iniciativa privada, pero el ministerio de Estado aviso a sus representantes para que secundaran la idea (1).

\section{UNA PRUDENCIA MAL ENTENDIDA}

Tenía España un limes con una nación que iba a convertirse en una potencia imperialista. Su población apenas alcanzaba una cuarta parte de la de Estados Unidos. No podía igualarse en recursos y desarrollo económico con su poderoso vecino en el Golfo de México. Esa realidad frenaba las reclamaciones que

SigLA UTILIZADA:

AMAE: Archivo del Ministerio Asuntos Exteriores. Madrid.

Proyecto financiado por DGICYT PS-91-0003.

(1) Los funcionarios españoles no debian formar parte de las Juntas Directivas, creadas con ese objetivo.

La carta enviada por los españoles en México, fechada el 28 de enero de 1896, proponía abrir una suscripción para incremento de la escuadra de manera que pudiera contribuir mejor a la defensa nacional. Era un compromiso que se ampliaba a un plazo de veinte años. La fundación definía la suscripción como "un impuesto voluntario". Cada junta local tenía plena libertad para fijar el modo de llevar a cabo ese propósito. Texto anexo a la Circular 4 del marqués de Amposta, subsecretario de Estado, 16 de marzo de 1896, AMAE, Circulares 2.734.

El presente trabajo se inserta en una investigación sobre las dimensiones diplomáticas de la guerra hispano-cubana. Uno de estos estudios apareció ya en esta misma revista: “1898: la batalla por la paz, la mediación de León XIII entre España y Estados Unidos", Revista de Indias, n 177, 1986, págs. 247-289. 
pudiera hacer el honor español. Había que disimular las injurias. Era el «handicap del aislamiento», del cual todos eran responsables (2). Existían razones para defender la soberanía de España en Cuba y se podía descalificar los motivos de los rebeldes. Había que disipar los errores de las personas imparciales (3). Se abría así el frente de la política exterior.

Necesitaba el gobierno de Cánovas la ayuda de las otras potencias. Podía contar con Francia, donde se estaba produciendo un "élan unanime» de la opinión en favor de España. Hanotaux, ministro de Negocios Extranjeros, afirmó ante el embajador de España que el gobierno de París compartía esos sentimientos (4). En contrapartida, España debía extender a las naciones amigas las garantías que había dado a los norteamericanos y aplicar a sus ciudadanos las normas recogidas en el protocolo hispanonorteamericano de 1877 (5). Era un ejemplo más para medir la dificultad de armonizar los puntos de vista de la diplomacia y las necesidades de la guerra. Había que compatibilizar ambas exigencias. Conforme avanzó la contienda y se hizo patente la urgencia de la cooperación internacional, fue primando la diplomacia (6).

(2) “¡Cuántos gobiernos y cuántos partidos han estado en España en el poder, desde hace muchos años, y han propendido al aislamiento, movidos por una prudencia mal entendida y por un concepto equivocado y mezquino de la importancia y del valor de la nación, cuyos destinos dirigían!". Era el juicio de Juan Valera, que había sido ministro de España en Washington. Apareció este artículo en el Diario de Cádiz, 13 de marzo de 1896, cit. por M. BARAJA, La guerra de independencia cubana a través del Diario de Cádiz. Cádiz 1979, pág. 289.

(3) El ministerio de Ultramar editó España y Cuba, un libro que aportaba datos oficiales sobre la situación en la isla y el régimen político-administrativo allí vigente. Era preciso difundir ese texto. Marqués de Amposta, circular s.n., 16 de abril de 1896, AMAE Circulares 2.734.

(4) Dos pruebas de esa actitud: se estaba impidiendo el embarque de armas para los rebeldes y se había autorizado la cotización en Bolsa de 320 millones de pesetas en billetes de Cuba. Había que conservar y fomentar ese clima para el caso de que hubiera de acudir a la suscripción de algún empréstito. Esta corriente de simpatía podría quebrarse si, por aplicación de leyes de guerra, un juicio sumarísimo condenara a muerte a un ciudadano francés y llegara a cumplirse la sentencia. El ministerio de Negocios Extranjero confiaba que no se fusilara a los franceses apresados con las armas en las manos, combatiendo al lado de los insurgentes. Confidencial. 133 Duque de Mandas-Duque de Tetuán, 19 de mayo de 1898, AMAE Política 2.416.

(5) En ese protocolo se concretaba el artículo 7 del Tratado de Amistad, Límites y Navegación, firmado el 27 de octubre de 1795. No podía acceder a ese ruego del ministro francés, pero España estaba dispuesta a aplicar el indulto caso por caso. Se había ordenado al capitán general que no se ejecutara ninguna sentencia de muerte, sin el visto bueno del gobierno. Real Orden. Tetuán-Mandas, 28 de mayo de $1896, i b .2 .416$.

(6) El expediente en torno a la solicitud del duque de Mandas concluyó con una citra del ministerio de la Guerra al capitán general de Cuba el 11 de abril de 


\section{MEMORÁNDUM A LAS POTENCIAS}

Fue la primera intervención importante del ministro de Estado para ordenar el problema cubano. Se proporcionaba así a los representantes de España una pauta común a la hora de explicar a los gobiernos ante los cuales estaban acreditados cuál era la posición de Madrid (7). Desde 1878, año de la Paz del Zanjón, la situación económica de Cuba era muy favorable. La cosecha de azúcar y la exportación de tabaco se habían duplicado. Se incrementó notablemente el comercio. La población creció desde 1.400.000 habitantes hasta 1.600 .000 entre 1879 y 1887. Los impuestos descendieron. Las reformas políticas y sociales fueron transcendentales en ese mismo periodo (8). Hubo una representación cubana de 30 diputados y 16 senadores en las Cortes. España era la garantía del progreso de Cuba. La rebelión carecía de legitimación (9). El desigual desarrollo entre Puerto Rico, donde se había preservado la paz, y Cuba denunciaba la falsedad de que la administración española era la causa de los males que afligían a los cubanos. La guerra hacía pesar sobre la isla una deuda que ascendía a 900 millones de pesetas.

1896. Al llegar los liberales al poder, una Real orden, del 11 de noviembre de 1897 dirigida a los capitanes generales de Cuba y Puerto Rico, les concedía la facultad de otorgar la gracia del indulto. Vid. Gaceta de Madrid, 12 de noviembre de 1897. texto reproducido en Colección Legislativa de España, $\mathrm{n}^{\mathrm{9}} 162$ (1897), Madrid 1906, págs. 430-431.

(7). El texto impreso: AMAE Política 2.416. Era un documento fundamental, que fijaba la postura española y las grandes líneas del análisis que hacía el gobierno de Cánovas. Se envió con carácter reservado. El duque de Tetuán escribió confidencialmente a algunos embajadores de España. Una visión global de su gestión política, DuOUe DE TETUÁN, A puntes del ex-ministro de Estado, auque de Tetuán, para la defensa de la política internacional y gestión diplomática del gobierno liberal-conservador, Madrid, 1902, 2 vs.

(8) Los cubanos gozaban de los mismos derechos que los demás ciudadanos españoles. Se había abolido la esclavitud por la ley del 13 de febrero de 1880 y por el Real decreto del 7 de octubre de 1886. Un Real decreto del 7 de abril de 1881 extendia a los habitantes de Cuba todos los derechos reconocidos en el título I de la Constitución. Fruto de una transacción política entre los partidos españoles y antillanos fue la ley del 3 de marzo de 1895, ampliando el régimen de gobierno y administración civil en Cuba y Puerto Rico. Creaba un Consejo de Administración y modificaba las normas que regulaban el régimen municipal y provincial para ajustarlas a las atribuciones de este nuevo organismo.

(9) Asi lo declaraba el memorándum del ministerio de Estado: "Los principios de especialización y amplia descentralización, vigorosamente desenvueltos en la novisima legislación, son acogidos con el levantamiento insurreccional. No se piden nuevas y amplias concesiones; no se lucha por adquirir derechos, por implantar libertades: a las va otorgadas, con el concurso de todos los partidos, incluso el autonomista, se contesta combatiendo contra la soberanía espanola, a la que Cuba debe, desde su descubrimiento, cuanto es y cuanto vale; se lucha por adquirir una independencia que, dado lo heterogéneo de las razas que existen en la Isla, su proporcionalidad y circunstancias especiales que las caracterizan, serían su absoluta ruina y la convertirían en campo de constantes e intestinas disensiones". 
No se iba a ahorrar esfuerzos para mantener en Cuba la soberanía española. Así lo probaban las diez expediciones enviadas con 127.000 hombres y estaba en preparación una de 40.000, a la que seguiría otra de 20.000. Sumados a los otros contingentes, la presencia militar de España llegaba los 200.000 hombres en armas. La firme decisión de mantener la integridad territorial era unánime en todos los partidos políticos. Cuba era innegociable. No eran desconocidas para el gobierno de Madrid la naturaleza de la contienda y las expectativas que los rebeldes tenían puestas en una confrontación internacional (10).

Se agradecía públicamente a Cleveland que su administración hiciera todo lo que las leyes le permitía para impedir que se enviaran auxilio a los separatistas. Los acuerdos del Congreso, en contradicción con la orientación de la Casa Blanca, las expediciones que desde las costas norteamericanas salían rumbo a Cuba, con la complicidad de algunas autoridades locales, estimulaban la rebelión. Se violaba las leyes de la humanidad y los tratados internacionales, que vetaban el envío de armas, municiones, explosivos, incluida la dinamita, con destino a los insurgentes. El gobierno de Washington había acogido las justas reclamaciones de España, pero ese comportamiento no había sido correspondido por quienes debían castigar a los culpables.

España denunció el funcionamiento, con absoluta publicidad, de una Junta, que se autoproclamaba organizadora de la rebelión armada. La prensa de Estados Unidos denigraba las instituciones españolas e insultaba a sus autoridades. Personas, con ciudadanía norteamericana, se autodesignaban representantes diplomáticos de un gobierno inexistente y amparaban la suscripción de empréstitos filibusteros (11).

Las elecciones venían a complicar la situación. El partido republicano, en su convención de San Luis, se había manifestado favorable a la independencia de Cuba, expresando su deseo de que desaparecieran del continente americano los dominios de las

(10) Era una guerra de emboscadas. Los jefes insurgentes no confiaban en una victoria. Se limitaban a esperar que el terreno y el clima fueran sus aliados. Alcanzarían sus objetivos cansando y agotando las fucrzas que los combatían. "En tales condicione's si no peligra ni puede peligrar por el solo efecto de las armas nuestra soberanía, la lucha se prolongará con exceso, alentados los insurrectos con el apoyo moral y material que les presta parte del pucblo de los Estados Unidos y en espera de conflictos internacionales. Este apoyo moral y material de los Estados Unidos y la esperanza de conflictos exteriorés es lo que evidentemente prolonga un estado de cosas tan contrario a los intereses generales de la humanidad v lan perjudicial para España y para cuantos países comercian con la Girande Antilla".

(11) Programa de los republicanos para las elecciones de 1896. Texto en $\mathrm{H}$. Rickovir, ('imo fue hundido el Maine, Madrid, 1986, pág. 34. 
potencias europeas. "Observamos con profundo interés la heroica batalla de los patriotas contra la crueldad y la opresión y fijamos las mejores esperanzas en el pleno éxito de su decidida lucha por la libertad. Por haber perdido el gobierno de España el control de Cuba y ser incapaz de proteger las propiedades o vidas de los ciudadanos americanos residentes o cumplir con sus obligaciones derivadas del Tratado, creemos que el gobierno de los Estados Unidos debe emplear activamente su influencia y buenos oficios para restablecer la paz y dar independencia a la İsla».

Esa nueva proclama de monroismo (12) era un motivo de solidaridad entre España y las potencias europeas, en previsión de un futuro cargado de riesgos. Las advertencias de Madrid iban más allá de las conveniencias diplomáticas (13).

El duque de Tetuán juzgó conveniente recordar en su memorándum los antecedentes de las pretensiones norteamericanas sobre Cuba, desde 1809 hasta que se produjo el grito de Yara en octubre de 1868 . Se mencionaba también la propuesta de «triple garantía», que hicieron Francia e Inglaterra a Estados Unidos de modo que Cuba quedase a salvo de cualquier peligro. Eran en 1852 ambas potencias representantes de los «intereses coloniales y marítimos de la Europa" (14). El ministro de Estado consideraba vigente aquella situación y solicitaba a Alemania, Italia, Rusia y Austria-Hungría que adoptaran una actitud semejante a la de Inglaterra y Francia. Había un dato nuevo, que venía a reforzar esa mancomunidad de las naciones europeas: la apertura del canal transoceánico en el Golfo de México (15)

Si Estados Unidos poseyera Cuba, aspiración que habían mos-

(12). La expansión imperialista se realizó en un contexto de agudización del monroismo. J. M. JOVER, Teoría y práctica de la redistribución colonial, Madrid 1979, págs. 8-9. Sobre el monroismo como ideología de dominación imperialista, vid. el apasionante y apasionado trabajo de J. VASCONCELOS, Bolivarismo y monroismo. Temas iberiamericanos, Santiago de Chile 1934.

(13) "De triunlar los ideale's sustentados contra España, de no remediarse en una u otras forma, las demasias de los que, alucinados por un mal entendido patriotismo, prescinden a todas horas de los respetos y de los deberes que la amistad internacional impone, los conflictos podrán surgir en cada momento, porque en la inmensidad de luerzas y de elementos que se han reunido en los Estados Unidos, se encontrarán constantemente medios para trabajar contra los interese's peculiares de cada Estado".

(14) Esta cra la propuesta franco-inglesa: “Vista vuestra declaración de que no toleraréis que una potencia curopea se apodere de Cuba, nosotros declaramos, a nuestra ve\%, que no consentiremos que pase del dominio de España al de otro país y para obviar todo recelo mutuo instamos a asociarse a una declaración de as ties potencias renunciando a la posesión futura de la Isla de Cuba".

(15) "Si algo ha variado e's, por múltiple's consideracione's, el mayor interés de Europa en America, acrecentado singularmente por la segura aperiura, en un porvenir más o menos próximo, de un canal interoceánico que impone la conveniencia del slatll ques en el Seno Mexicano, en el orden de los interese's políticos y comerciales". 
trado en varias ocasiones y concretado en proposiciones de compra a diferentes gobiernos de Madrid, se produciría una modificación radical (16). Esta era la causa de que el significado de la no intervención en asuntos internos, tan claramente definido en la guerra de secesión, no se aplicara con equidad antes y después de declarar beligerantes a los separatistas. España estaba segura de que la insurrección no tenía futuro, si se le privaba de ayuda exterior. Un pronto final conjuraba todos los peligros que pudieran correr las naciones amigas. No rehuía la Nota un aspecto delicado: la carencia o no de medios jurídicos que permitieran a la administración Cleveland cumplir sus obligaciones con España, en justa correspondencia con el comportamiento de las autoridades cubanas durante la guerra civil americana. La escasez de esos recursos legales no justificaba la falta de diligencia. Este principio de derecho hallaba en un jurisconsulto norteamericano un aval. Caleb Cushing se asociaba a las declaraciones de los ex presidentes Van Buren, Taylor, Fillmore, Pierce y Arthur en las proclamas que publicaron en circunstancias anteriores.

Otro aspecto del litigio jurídico era el protocolo de 1877, que concretaba el alcance del artículo 7 del Tratado de 1795. Washington le estaba dando una interpretación excesiva. El duque de Tetuán recordaba que, en su artículo 1, se delimitaba el ámbito de aplicación: los norteamericanos residentes en Cuba, pero no se extendía a quienes desembarcaban para unirse a la rebelión.

Encontraron los revolucionarios cubanos amparo en la condición de ciudadanos de Estados Unidos que tenían algunos de sus cómplices y cooperadores. Era una verdad admitida que había casos en que las autoridades locales norteamericanas abusaban en la concesión de estas certificaciones. España había planteado ya el problema ante la comisión de arbitraje, que discutió las reclamaciones de quienes habían sufrido daños con motivo de la guerra de 1868-1878 (17)

Echaba en falta el gobierno de Madrid una proclama similar a la del presidente Taylor en 1849, poniendo en vigor las leyes especiales de 1838. Se superaría así las lagunas de legislación

(16) “... el concepto norteamericanos sobre la Gran Antilla es que ha de formar parte de la confederación americana".

(17) E. Muruaga, entonces ministro de España en Washington, estaba satisfecho de la respuesta dada a esa demanda. La guerra de 1895 demostraría que era un contencioso sin resolver. Era el momento de recordar la afirmación del Tratado de 1795. Confiaba el gobierno español que, satisfaciendo los sentimientos en él expuestos y cumpliendo los compromisos que allí se fijaban, "desapare(ciera)n los auxilios morales y materiales que la insurrección cubana recibía en el territorio de la Unión". 
ordinaria supliendo el escaso celo de los funcionarios. Se solicitaba la asistencia de los gobiernos de las potencias europeas para animar al de Estados Unidos a fin de encontrar, junto con el de Madrid, "los medios eficaces para impedir que la insurrección continuara, siendo dirigida y fomentada desde territorio americano, apresurando así el momento de la pacificación y con ésta el de la posible aplicación de las reformas of recidas». Era inquebrantable el propósito de España: iba a conservar intangible su integridad territorial. Existía la amenaza de que se rompiera la paz entre dos pueblos, "causando a todos los países daños de extraordinaria cuantía». Sentimientos amistosos y prudencia exquisita serían la norma en las relaciones de España con Estados Unidos. Respecto a Cuba, deseaba la concordia. El único límite era la soberanía irrenunciable. Salvándolo, ningún obstáculo impediría las patrióticas concesiones. Para garantizar esos planes, acudía España al "recto juicio y a la amistad de las grandes potencias de Europa", en nombre de su propio bienestar y en el interés supremo de la paz, de la justicia y de la humanidad.

\section{Gestiones en San Petersburgo}

La mediación europea en favor de España iba a centrarse en Rusia. Drummond Wolff había informado a Salisbury. Así se le comunicó al conde de Casa Valencia. El premier inglés se mostró partidario de centralizar todas las gestiones en Rusia. El embajador en Londres debería insistir ante el Foreing Office para que apoyara eficazmente la acción de España ante el gobierno del zar (18). El conde Dubsky, embajador austríaco en Madrid, había colaborado en los contactos del ministro de Estado con los representantes de las otras potencias. Se había entrevistado con ellos. Austria estaba también conforme en que fuera Rusia la que asumiera la dirección en la mediación. La influencia de Viena era decisiva. El zar mantenía con Francisco José las mejores relaciones. Rusia suscitaba menos recelos en Estados Unidos.

(18) Drummond Wolf se había traído de Londres esa promesa. Inglaterra no negaría su cooperación para negociar con Estados Unidos, aunque no podía implicarse en ella para no lesionar sus propios intereses en las relaciones con Washington. Tetuán-Concle de Casa Valencia, 28 de julio de 1896, AMAE Política 2.416. Sobre la actuación del embajador del Reino Unido. Vid. Rosario de la TORRE, Inglaterra y España en el 98, Madrid 1988, págs. 78-85, 132-149. Vid. también su trabajo, "La crisis de 1898 y el problema de la garantía exterior". Hispania, no 162, Madrid, 1986, pág. 124. 
Sus vínculos con este gobierno eran muy estrechos en esos momentos (19).

Según el embajador alemán, el memorándum iba a tener una acogida favorable. Elegir a Rusia era el modo más eficaz de lograr el alineamiento de Berlín y su mediación ante Nicolás II. A fines de agosto, se reunirian en Viena los tres Emperadores (20). Fue el barón de Renzis quien sugirió la iniciativa de primar el papel de Rusia. Francia pondría todo su peso para conseguir que San Petersburgo aceptara (21). En las instrucciones al embajador ante la III República se omitían las referencias a la solidaridad monárquica y a la Triple Alianza (22).

Eran prematuras las expectativas. No era fácil que Rusia aceptara esa invitación que, de diferentes maneras, le iban a hacer llegar las potencias. La Regente escribió personalmente al zar. La carta se entregó al embajador ruso en Madrid. Francisco José ejercería sus buenos oficios durante el encuentro de Viena (23).

Se organizó en París un encuentro de funcionarios diplomáticos, a quienes se les entregó unos pliegos para los embajadores de España en Roma, Viena y Londres (24). Se suspendió la entrega del memorándum tras la reacción de Estados Unidos, pero se ordenó que se retuviera toda la documentación remitida con ese

(19) Se encomendaba al marqués de Hoyos que subrayara en carácter general y vago las demandas de España con el fin de que Austria exigiría un tono más vigoroso. Tetuán-Hoyos, 28 de julio de 1896, ib. 2.416.

(20) Se le decía a Felipe Méndez Vigo: “... no estaría tampoco de más aluda a lo que a la Triple Alianza misma interesa que, ante las contingencias y eventualidades del porvenir, España, cuya vitalidad se está demostrando con motivo de la insurección de Cuba, se vea desembarazada y libre de compromisos y sacrificios que esta insurrección la obliga". Tetuán-Méndez. Vigo, 28 de julio de 1896, ib. 2.416.

(21) A Italia se le pedía únicamente que se sumara a las demás potencias en este proceso. Para ella, miembro de la Triple Alianza, eran también importantes las consecuencias que la conclusión del problema cubano tendría de cara a los acontecimientos que pudieran surgir, dadas las tensiones internacionales existentes. Tetuán-conde de Benomar, embajador ante el Quirinal, 28 de julio de 1896, ib. 2.416.

(22) Tetuán-duque de Mandas, 28 de julio de 1896, ib. 2.416. No era un ejemplo de astucia, sino una prueba de inconsistencia.

(23) Se insistía ante el conde de Villagonzalo en la trascendencia de que Rusia asumiera ese ruego de las otras potencias. "...lograr (que Rusia acepte el encargo) es para nosotros de la mayor importancia". Tetuán-conde de Villagonzalo, 28 de julio de 1896, ib. 2.416.

(24) El 9 de agosto saldría hacia San Petersburgo un correo con esos mismos pliegos y con una cifra especial. Cifra. Tetuán-Villagonzalo, 8 de agosto de 1896. Ese mismo día se envió una cifra con idéntico contenido a Méndez Vigo, embajador en Berlín. 
motivo (25). Taylor, ministro plenipotenciario de Estados Unidos en Madrid, se entrevistó con el duque de Tetuán. Fue una conferencia amplia y amistosa. Las conclusiones fueron "completamente satisfactorias para ambos». Había que frenar la mala impresión que la noticia sobre el memorándum podría suscitar en el secretario de Estado (26).

La situación daba un giro que beneficiaba a España. El duque de Tetuán informó a Cánovas. Era preciso reconocer que el aplazamiento suponía un gran contratiempo. Había sido una sugerencia de Drummond Wolff, el embajador inglés, que se entrevistó con el ministro de Estado. La idea no fue una sorpresa para Tetuán, que venía observando la actitud de los representantes de las grandes potencias. España tenía el deber de informar y el memorándum era una forma razonable de cumplirlo. La proclama de Cleveland, sobre la que volveremos más adelante, modificaba radicalmente la situación. El presidente y el secretario de Estado Olney inspiraban plena confianza al gobierno de Madrid, que había intentado únicamente prevenir riesgos (27).

Drummond Wolff comunicó a Tetuán el disgusto de Taylor cuando se enteró, de modo reservado, de la existencia del documento. Al margen del sentido que se le diera al texto, sería una ofensa para Cleveland y su administración, cuya lealtad se ponía en duda. Salían reforzados los partidarios de los insurgentes y los que se oponían a la continuidad de España en Cuba. Prevista para el 10 de agosto la entrevista con el ministro norteamericano, quiso Tetuán conversar antes con el representante de Francia, que esos días estaba en San Sebastián. Le manifestó el mismo criterio que Wolff. No quedaba más que telegrafiar a los embajadores españoles y anunciarles la decisión (28).

(25) Cifra del ministro de Estado a los embajadores en Roma, Berlín, Viena, Londres y San Petersburgo, 10 de agosio de 1896, ib. 2.416.

(26) Cifra. Tetuán-ministro plenipotenciario en Washington, 11 de agosto de 1896, ib. 2.416.

(27) Tetuán se limitó a prometer a D. Wolf que reflexionaría sobre la idea que le había expuesto.

(28) Tetuán-Cánovas, 11 de agosto de 1896 y Cánovas-Tetuán, 13 de agosto. En cuanto al memorándum, decía el presidente del consejo: "Puede declararse que el documento queda en poder de nuestros representantes a título de mera instrucción para poder explicar y noticiar la situación de Cuba y la actitud del gobierno, cuando sea indispensable, pero sin leérselo y menos dejar copia a nadie. Telegrafic, porque lo que importa es que adoptemos un sistema". AMAE Política 2.416. 


\section{ENTREvista Tetuán-TAYlor}

Pese al disgusto de Cánovas, la tentativa española de implicar a las demás potencias, pudo valorarse como un gesto de dignidad. Así lo hicieron notar a los representantes españoles y esa fue la impresión que recogió algún diario europeo (29). ¿Se había precipitado el gobierno de Cánovas al pedir una mediación innecesaria? En los meses anteriores la administración Cleveland había mostrado su buena voluntad. En los días inmediatos al envío del memorándum, el presidente había reiterado su voluntad de hacer cumplir las leyes de neutralidad. Recordaban Cleveland y su secretario de Estado la advertencia que el 12 de junio del año anterior se había dado a los ciudadanos norteamericanos a raíz de los "disturbios civiles" y de la "resistencia armada al gobierno constituido" de España, "con la cual los Estados Unidos esta(ba)n y desea(ba)n continuar en terminos de paz y de amistad". El contenido de las normas era evidente (30). Había ahora una interpretación autorizada, emanada del Tribunal Supremo, declarando como se quebrantaban los preceptos de las leyes de neutralidad. Cleveland resumía en su proclama la resolución de la más alta magistratura jurisdiccional norteamericana. Admitía, de alguna forma, las reclamaciones de España, al recoger en uno de sus considerandos que había razón para creer que ciudadanos de Estados Unidos y otros que estaban bajo su soberanía transgredían las leyes y participaban en transacciones que las violaban.

(29) El barón Marshall manifestó su conformidad con la conducta de España. Cifra. Méndez Vigo-Tetuán, 16 de agosto de 1896, ib. 2.416. The Standard, en su edición del 11 de agosto, publicaba un telegrama en el que se calificaba muy positivamente la acción del ministerio de Estado. El diario conservador planteaba la mediación amistosa de las potencias ante Cleveland y ante el pueblo de Estados Unidos, a fin de lograr la observancia estricta de las leyes de neutralidad. Vencida así la insurrección, Madrid introduciría reformas en la administración colonial. Se hacía eco también The Standard de la entrevista de Tetuán con Taylor y comentaba sus resultados. 593 Conde de Casa Valencia-Tetuán, 11 de agosto de 1896, ib. 2.416.

(30) La proclama del 12 de junio lo resumía así: "prohiben a sus ciudadanos así como a todos los que estén dentro y sujetos a su jurisdicción tomar parte en tales disturbios en contra de dicho gobierno constituido, o ejecutando comisiones para servicios de guerra contra él, alistándose o procurando que otros sé alisten para este servicio, equipando o armando o procurando que sean equipados o armados buques de guerra para este servicio, aumentando la fuerza de cualquier buque de guerra dedicado a tal servicio, que arribe a un puerto de los Estados Unidos, e incitando, o facilitando o preparando medios para conducir expediciones militares desde los Estados Unidos contra el territorio de dicho gobierno". No podía ser más explícita la condena contra los laborantes y contra las expediciones filibusteras. Sobre éstas y su represión, vid. C. RoBles, "La oposición al activismo independentista cubano". Hispania, no 168, Madrid, 1988, págs. 227-288. 
Todas esas conductas serian en adelante "vigorosamente perseguidas» (31) Estos eran los antecedentes de la entrevista que tuvo lugar en San Sebastián el 10 de agosto (32).

Tetuán informó a Taylor de la conversación mantenida con Drummond Wolff. Se quejó amistosamente de que el ministro norteamericano no hubiera ido directamente a él para manifestarle que se sentía molesto por el memorándum. Era el comportamiento lógico, teniendo en cuenta la cordialidad y franqueza con la que se desarrollaban las relaciones desde la llegada al poder del ministerio conservador. Cánovas y él mismo habian hecho declaraciones en las Cortes resaltando la lealtad y agradeciendo la buena voluntad de Cleveland. Habían tenido Taylor y el duque de Tetuán ya una entrevista días antes. Procedieron a un leal intercambio de ideas y aspiraciones, con el fin de llegar a una pronta pacificación en Cuba (33). Insistió Tetuán en el carácter preventivo de las observaciones que España consignaba en el documento. Ninguna de ellas podía molestar a las autoridades norteamericanas.

La Nota del 4 de abril era resultado de las informaciones que él había enviado, pero Taylor la atribuyó a la secretaría de Estado. No entendía que España estuviera obligada a exponer a las potencias europeas «los antecedentes, estado actual y consecuencias que podian derivarse de la insurrección de Cuba». Juzgó un error ese acto porque podría enemistar a España con Estados Unidos. Era una decisión que corría el riesgo de anular todos los esfuerzos tendentes a una "solución amistosa". La opinión norteamericana podría inclinarse a favor de los rebeldes. Era urgente establecer una sintonía entre la acción militar para llegar a la pacificación y la política de Washington, teniendo en cuenta que

(31) La proclama Cleveland-Olney-estaba fechada el 27 de julio, es decir un día antes que el memorándum del duque de Tetuán. El ministro de España envió el texto inglés y la traducción unos días más tarde, 146 Dupuy-Tetuán, 12 de agosto de 1896, ib. 2.416.

(32) Seguimos el informe que el ministro de Estado hizo a Cánovas en su carta del 11 de agosto y unos "Apuntes de una conferencia celebrada en San Sebastián el día 10 de agosto de 1896 entre el Excmo. Sr. Duque de Tetuán, ministro de Estado, y el Excmo. Sr. Hannis Taylor, ministro plenipotenciario de los Estados Unidos". AMAE Política 2.416.

(33) No eran solamente cordiales estas relaciones en el terreno personal y oficioso. La respuesta de España a la Nota de Olney, del 4 de abril de este mismo año, no ahorraba elogios hacia Estados Unidos y manifestaba la plena confianza en el Presidente y en su administración. 
se estaba a siete meses de las elecciones presidenciales (34). Aunque se produjera un cambio en la administración, España contaba con tiempo suficiente para dominar la situación. Así lo creía Taylor.

No era tan sencillo el problema. El ministro de Estado estaba seguro de que, libre España de preocupaciones exteriores, podría concentrar sus esfuerzos y sus medios en resolver la sublevación. Pero la solución no estaba en La Habana, sino en Washington: la guerra continuaba gracias a los auxilios que los separatistas recibían de Estados Unidos. Si había tomado la decisión de enviar el memorándum fue previendo que la situación militar se mantuviera sin cambios. Iba a consultar Tetuán a Cánovas acerca de la oportunidad de bloquear la entrega de la Nota de España a las potencias. Taylor reiteró su petición de que, en cualquier caso, se aplazara a la espera de los resultados de la campaña de otoño. Asumía el compromiso de informar a su gobierno, para destruir todo equívoco (35). Había cordialidad en las relaciones entre el representante norteamericano y el duque de Tetuán. Taylor avisó que el mismo corresponsal que le había revelado la existencia del documento había marchado a la frontera francesa para telegrafiar a Londres y Estados Unidos. Era conveniente avisar al ministro de España en Washington. El secretario Olney y Dupuy debía estar prevenidos para que no les sorprendieran las impresiones desfavorables que podría generar la noticia acerca del memorándum.

Había que proceder con cautela. Los ministros de Negocios Extranjeros de las potencias conocían la iniciativa española. Ahora debía justificarse la resolución de no consignar el documento. Podría ser una explicación verbal, que permitiera a España cono-

(34) Según Tetuán, Taylor había afirmado que "ningún presidente ni secretario de Estado podíamos esperar más amigos de España y que, si insistíamos en el paso que íbamos a dar, todos sus propios esfuerzos se habrian esterilizado y sólo encontraríamos hostilidad, más o menos encubierta, donde de veras y sinceramente se nos quería ayudar; concluyendo por pedirme y aún rogarme encarecidamente que, si todavía era tiempo, detuviéramos nuestra acción, no avanzando hasta un término que pudiera ser irreparable y esforzándose en convencerme de que me lo pedía inspirándose en verdaderos sentimientos de amistad e interés por España y de los que estaba seguro participaba también Cleveland y su gobierno". Como prueba de esa buena voluntad, le dio una noticia confidencial: sabía que España no podía contar con el apoyo de ninguna potencia de Europa. Desmentía así las aseveraciones del ministro de Estado. Afirmaba que los embajadores de Inglaterra y Francia estaban quizás haciendo un doble juego.

(35) Taylor dijo a Tetuán que debía comunicar el contenido de esta estrevista a sus colegas francés e inglés, porque ambos estaban enterados y esperaban las conclusiones a las que se llegara en ella. 
cer la actitud de esos gobiernos ante el problema cubano. Había aún razones para el optimismo (36).

Se ordenó a Dupuy que esperara instrucciones. Entretanto, debía suavizar asperezas y atenuar el efecto negativo que la noticia acerca el memorándum hubiera podido causar (37). Y se informó de la entrevista con Taylor a los destinatarios del memorándum (38). Las impresiones no fueron las esperadas. En Italia se decía que no había ambiente para un acuerdo entre las potencias. Según Visconti-Venosta, la decisión de suspender la entrega del memorándum era un acierto (39). Esa misma fue la impresión que transmitió el príncipe de Lobanoff al embajador en San Petersburgo (40). Cuando el marqués de Hoyos explicó las razones de España y las que abogaban por una intervención europea, el conde de Goluchowski, ministro austríaco de Negocios Extranjeros, se abstuvo de opinar (41). Alemania se limitó a aprobar el comportamiento de España en su fondo y forma (42). Prudente juzgó Hanotaux la decisión de retirar el memorándum,

(36) "... creo que habremos conseguido mucha parte de lo que con el Memorándum nos proponiamos. El gobierno americano sabe ya que teníamos preparada una acción que, estando sólo suspensa, es susceptible de ser reanudada a nuestra voluntad. Las grandes Potencias no podrán negar nunca que conocen nuestros propósitos y aspiraciones y como todas probablemente aprobarán la conducta que hemos seguido, resultarán implicitamente asociadas a la responsabilidad de nuestra resolución". Tetuán-Cánovas, 11 de agosto de 1896, AMAE Política 2.416.

(37) Cifra. Tetuán-Dupuy, 20 de agosto de 1896, ib. 2.416.

(38) La proclama de Cleveland, fechada el 30 de julio, habia modificado el criterio de los embajadores de Francia e Inglaterra. Ni debía leer ni dejar el texto, sino limitarse a una exposición verbal y declarar que se hablaba a título meramente informativo. Si tenían alguna duda, debian consultar al ministerio de Estado. Cifra. Tetuán-embajadores de España en Roma, París, Viena, Berlín, San Petersburgo y Londres, 14 de agosto de 1896, ib. 2.416.

(39) El conde de Benomar había informado que España tenía 200.000 hombres en armas y que iba a derrotar a los independentistas. "Mi impresión es que... la Europa, preocupada hoy por la cuestión de Oriente y consciente de las resoluciones y convenios que la esperan del viaje por Europa de S. M. el Emperador de Rusia, no se movera sino ante la inminencia de un conflicto entre España y los Estados Unidos, provocado por la mala voluntad del gobierno anglo-americano; conflicto, cuyas graves consecuencias a nadie se ocultan; que la proclama de presidente Cleveland alejando tal conflicto y dando ocasión a España para obtener del gabinete de Washington que tiene interés en detener la intervención de Europa, alguna parte de las concesiones que el gobierno español esperaba obtener por la acción combinada de las grandes potencias, hace difícil que la Europa entre ahora, ni aún confidencialmente, en acuerdos y conciertos para eventualidades que considera lejanas". 176 Benomar-Tetuán, 17 de agosto de 1896, bi. 2.416. El embajador ante el Quirinal era uno de los mejores diplomáticos de su tiempo.

(40) 53 Villagonzalo-Tetuán, 17 de agosto de 1896, ib. 2.416.

(41) Reservado. 67 Hoyos-Tetuán, 17 de agosto de 1896, ib. 2.416.

(42) Así se lo dijo el barón Marshall al embajador en Berlín. 145 Méndez. Vigo-Tetuán, 18 de agosto de 1896, ib. 2.416. 
sobre todo en un año de elecciones presidenciales. París tampoco se comprometía con España, porque la posición internacional de la República no se lo permitía (43).

Todo concluía con una Real orden, del 10 de octubre (44). Se habia evitado crear fricciones con Estados Unidos y se había conseguido que las naciones de Europa consideraran que el problema cubano les concernía. Había que recordar que en el origen de la iniciativa del ministerio de Estado estaba la sugerencia de los embajadores de esas potencias en Madrid.

\section{5. ¿UN PACTO CON LOS CUBANOS?}

La negociación estaba condicionada por la definición dada al conflicto (45). A lo largo de 1896 hubo contactos con los separatistas. Entre los políticos españoles, ni siquiera los republicanos, con la excepción de los federales, eran partidarios de la independencia (46). Hubo propuestas. Una de ellas fue la de Joaquín Henrich, Salvador López, un rico español residente en París, y J. S. Pérez redactor jefe de la Correspondance Bleue, que preparaba una entrevista de Betances con "un personaje de Madrid», sobre la base de unas proposiciones similares a las que dieron la independencia a Canadá. Pérez sugirió que el plan, promovido por un

(43) No había sido informado el ministro francés de esa determinación del gobierno de Cánovas, porque su representante en Madrid estaba enfermo. Hanotaux alabó el patriotísmo de Cánovas y sus ministros y el heroísmo de los soldados españoles. El gobierno de Madrid estaba demostrando serenidad, energía y elevación de miras. 280 Duque de Mandas-Tetuán, 10 de septiembre de 1896, ib. 2.416 .

(44) Dirigida a los embajadores ante las potencias. AMAE Política 2.416. Se dio traslado de la misma al ministro de España en Washington. Real orden. Tetuán-Dupuy, 19 de octubre de 1896, ib. 2.416.

(45) Cuando la crisis derivó hacia una guerra internacional, que no podía ser más que una derrota para España, en aquellas semanas dramáticas de 1898, fue este el aspecto que fijó la posición negociadora de España y que condujo inevitablemente a ese desenlace. He tenido ocasión de tratar este punto en 1898: diplomacia y opinión, Madrid, 1991.

(46) Salmerón creía que no había llegado el momento. Ahora la mejor solución era la autonomía. Había que poner fin a una contienda que estaba desangrando y arruinando a España y a la isla. "¿No cree V., como yo, que evitando injerencias extrañas, para una y otra parte depresivas y a la postre quizás más funestas para los que aparentaran proteger, se debiera poner término a la guerra, gestionando el reconocimiento de la autonomía? Yo tengo por seguro que se vencería aquí rápidamente la torpe resistencia de estos gobiernos monárquicos...". Salmerón-Betances, 30 de marzo de 1896. Era respuesta a la que el delegado cubano en París había escrito el 20 de ese mes al jefe republicano español. En ella le rogaba que entregara los socorros que enviaba a los cubanos confinados en Ceuta. Betances envió copia de esta carta. 
ministro muy influyente, estaba aprobado por la Reina Regente (47).

Betances no creía que España comprendiera la autonomía. Esta comportaba ausencia de soldados y buques de guerra. Los independentistas ofrecían una indemnización, que debería pactarse, pero otorgando pleno autogobierno a cada una de las dos Islas. Después de un período de diez años, si Cuba y Puerto Rico no querían ese régimen, se procedería a la separación completa, sin represalias económicas y en paz. Todo esto sucedía en el momento en que Estados Unidos proponía sus buenos oficios para mediar (48).

A finales de septiembre de 1896 volvía a informar Betances acerca de las intenciones de Cánovas. Se haría un esfuerzo extremo y, a la vista de los resultados, se fijaría el término de la guerra en Cuba. La rebelión que se había iniciado en Filipinas era mucho más grave de lo que parecía (49).

El delegado cubano en París envió una nueva proposición de armisticio: evacuación de Cuba por las tropas españolas, conservando un simulacro de soberanía, la bandera y un tributo. El modelo podía ser Egipto y sus relaciones con el sultán de Turquía. Sagasta aceptaría y accedería al poder en cuanto el gobierno cubano quisiera entrar en negociaciones sobre esa base. Cánovas se retiraría (50). Estaba convencido Betances de que España quería salvar su honor y, pasados dos o tres años, se marcharía de la

(47) "Todo esto prueba que España aceptaría un arreglo con Cuba, de potencia a potencia, por evitar una intervención de los Estados Unidos, lo que debe tenerse en cuenta, si es verdad que el gobierno de Washington se informa cerca del de Madrid de la especie de autonomía que daría a Cuba y si piensa que tal vez pueda conseguirse más tratando directamente que dejando al gobierno americano obrar por nosotros". BETANCES-ESTRADA, s. f.: Correspondencia diplomática de la Delegación Cubana en Nueva York durante la guerra de la independencia de 1896 a 1898, 5 vols. La Habana 1943-1946, III págs. 23-24.

(48) La Constitución de la República de Cuba ponía como condición previa a toda negociación el reconocimiento de la independencia. BETANCES-EsTRADA, París 14 de mayo de 1896, III [47] pág. 29.

(49) “Cánovas se propone hacer lo imposible, como ha dicho él, durante esta estación seca y, si no obtiene mejor resultado que hasta ahora, se retirará del poder y cederá el puesto en marzo a Pidal, cuya misión sera 'firmar la evacuación de Cuba'. Este informe me llega por uno de los nuestros, de la embajada española... Ninguno de los ministros - ni el mismo Cánovas- cree hoy que España pueda dominar la revolución, pero hacen un esfuerzo desesperado. La insurección de Filipinas es mucho más seria que lo que se pensaba. Se propone el gobierno mandar no 8.000 sino 15.000 hombres". Betances-Estrada, 29 de septiembre de 1896: [47] III, págs. 71-72.

(50) "Si eso, que me parecía serio y digno de discutirse, no conviene, sírvase ponerme cuanto antes este cablegrama: "Imposible"'. BeTANCES-EsTRadA, 2 de octubre de 1896, [47], III, págs. 74-75. 
Isla (51). Estuvo atento Betances a las variaciones de la política interior española y a sus repercusiones en la cuestión cubana. A principios de diciembre comentaba una audiencia de Sagasta con la Regente. La situación era preocupante. Podía relevar el partido liberal a Cánovas, de acuerdo quizás con Martínez Campos. Debía coincidir con el comienzo de las negociaciones que se entablarían en París. Sería comisionado el conde de Rascón, antiguo embajador en Roma, Constantinopla y Berlín (52). El escritor John dos Passos patrocinó otro intento de negociación. Se presentó con una carta dada por Gonzalo de Quesada. Betances lo puso en contacto con el banquero Leonce Bloch. Dos Passos comunicó a Bloch sus intenciones de negociar con Cánovas, pero el banquero francés se negó a conversar con él, si no estaba delante Betances. Reunidos los tres, dos Passos expuso su plan: autonomía amplia, Tomás Estrada sería gobernador civil y Martínez Campos, gobernador militar.

Había contradicción entre esa propuesta y la posible evacuación de las tropas españolas. Las conversaciones duraron tres días (53). ¿Era una gestión semioficial la que estaba llevando a cabo el escritor norteamericano? En su camino hacia Madrid, Woodford, el nuevo ministro de Estados Unidos, recibió a dos Passos y se mostró muy reservado, según informes de Betances (54). En todo caso, no deja de ser significativo ese encuentro. El escritor, convencido de que la autonomía era insuficiente para satisfacer las demandas cubanas, marchó a Londres e interrumpió su comunicación con Betances (55). Con instrucciones de Nueva York y sobre la base de la independencia, Betances prosiguió sus esfuerzos por la pacificación, pero le faltó una autorización plena y no llegó a formular un plan completo para discutirlo con sus interlocutores. Esto era especialmente urgente después de que Bloch informó a Betances que los norteamericanos iban a endu-

(51) "... España se conformaría con una denunciación del Tratado, retirando su bandera y cambiando el tributo por una indemnización, en resumidas cuentas, cuestión de palabras". Betanctis-Estrada, 9 de octubre de 1896, [47], III, pág. 78.

(52) Betances-Estrada, 4 de diciembre de 1896, |47|, III, págs. 83-84.

(53) Bloch era amigo de Cánovas y se prestó a solicitar una entrevista con el presidente del gobierno español. Betances sabia que Estrada no aceptaria v que Cánovas tampoco se mostraría conforme con la propuesta. Alirmó que deberian enviarle desde Nueva York una plenipotencia. Dos Passos sugirió que se telegrafiara a Estrada, indicando la conveniencia de que Horacio S. Rubens y Gonzalo Quesada se incorporasen a la negociación de París. Betances juzgó que el viaje cra inútil. Creía que dos Pasos estaba comisionado por linancieros norteamericanos. Bi:TANCES-Estrad)a, 6 de agosto de 1897, |47|, III, págs. 101-10 3.

(54) Betances-Estrada, 27 de agosto de 1897 |47|, III, pág. 106.

(55) Be:tances-Estrad)a de septiembre de 1897 |47|, III, pág. 107. 
recer su actitud hacia los cubanos y la Junta de Nueva York (56). Fue entonces, cuando Canalejas, camino de Cuba, se entrevistó en París con Betances, quien juzgó de modo sumario e injusto al político español (57). A las consideraciones de Canalejas acerca de la autonomía y de la aproximación de políticos como Eliseo Giberga, José del Perojo y Rafael Montoro, contestó Betances que, tanto el ejército revolucionario como la emigración habían proclamado «independencia o muerte" y que, por consiguiente, sólo cabía negociar la independencia (58). Era una condición indiscutible (59).

Otra mediación fue la del presidente dominicano Ulises Heureaux a través de Jaime Vidal, que la llevó ante Estrada. El jefe de la delegación cubana en Nueva York respondió que no era un conflicto entre España y Estados Unidos. Por eso la base de la mediación era que España negociara con los revolucionarios. De no ser así, sólo quedaba la guerra como salida. El proceder de España los había empujado a la violencia, como «ultima ratio» (60).

\section{LAS CONTRIBUCIONES DE GUERRA}

Las aportaciones económicas de la emigración fueron cruciales para financiar los preparativos de la guerra de independencia. Las medidas que podían afectar a cualquiera de las partes beligerantes eran examinadas con atención y se calibraba su impacto en el enemigo. Para impedir que los tabaqueros cubanos en Florida sostuvieran con sus cuotas a los sublevados, se fijaron restricciones a la exportación de tabaco. Eso afectó a la situación laboral de la emigración (61). Por parte de los independentistas, Estrada envió instrucciones a Betances. Podría convenir con los propietarios de ingenios una protección a la zafra a cambio de

(56) "Si es así, se haría mal en perder un tiempo precioso, que podria emplearse en negociar y obtener tal ver condiciones ventajosas". BLoCH-BETANCES, Biarritz, 2 de septiembre de 1897 [47], III, págs. 108-109.

(57) “... intelectualmente me ha parecido... algo vulgar y lísicamente sucio. Me han dicho que, corruptor por instinto y por principios, tiene la pretensión de separar de nucestro partido a algunos jefes, fuera y dentro de la revolución y que va con misión de la Reina Regente".

(58) Betances-Estrada, 22 de agosto de 1897 [47] III, págs. 116-117.

(59) Asi se lo recordó Estrada a Bentances. Era una exigencia "formosa e includible". Estraida-Btitanctis, 1 de junio de 1896: [47] l, pág. 44.

(60) "Los intereses morales y materiales de Cuba y España son incompatibles, de aqui la necésidad de la separación absoluta". Esitradsa-VIDAL., 9 de junio dé 1896, |47], I, pág. 53.

(61) "Aqui están hoy paradas algunas de las tabaquerías y el resto del trabajo, poco e irregularmente. Espero que este estado económico pásará muy pronto". J. D. P(oyo-estrad)a, 28 de agosto de 1895: La revolución de 189.5 I, La Habana 1932, pág. 221. 
50 centavos por saco y anticipando la mitad del importe correspondiente a la totalidad de la cosecha (62). Por este motivo una de las decisiones de Weyler que más podia dañar a los rebeldes era la supresión de la zafra y de la molienda (63).

El gobierno revolucionario dictó el 14 de septiembre una tasa del $2 \%$ como aportación al empréstito en favor de la insurrección. Se debía entregar sobre el monto total del valor de sus bienes y a un interés del $6 \%$. Los que no obedecieran esa disposición se considerarían enemigos y sus propiedades serían destruidas 0 confiscadas (64). Se corría un riesgo: se podía perjudicar a personas que favorecían a la revolución y que habitaban fuera de la isla. Había que estar alerta y no enemistarse con los simpatizantes ni destruir la imagen de orden y autoridad que estaban dando los rebeldes, defendiendo las personas y los bienes con mayor firmeza que las autoridades españolas. Así lo advirtió Betances.

Presionaron los insurgentes a compañías norteamericanas que operaban en Cuba. Pidieron el pago de una contribución a los Ferrocarriles de Sabanilla y Maroto. La amenaza era apremiante: volarían los trenes con dinamita y destruirían las vías con disparos de cañones de largo alcance, inutilizando los esfuerzos de los soldados españoles para proteger las instalaciones. No se doblegaron los norteamericanos. Esa transgresión de las leyes de neutralidad colocaba a los independentistas en una posición difícil con la administración de Washington (65).

(62) Estrada-Betances, 30 de julio de 1896 [47], I, págs. 65-57. EstradaBETANCES, 25 de agosto de 1896, ib. 75.

(63) “... nos privaría desde luego de los fondos que pensamos reunir por medio del permiso concedido a algunos propietarios para que sus ingenios moliesen. Privados de este recurso en este periodo decisivo de la revolución, nos veríamos en la impotencia, dolorosa y desesperante, de continuar enviando a nuestros hermanos en armas los elementos de guerra que han de dar la victoria a la causa cubana en la próxima campaña de la seca". EsTRADA-BETANCES, 29 de agosto de 1896, [47], I, pág. 76.

(64) Un ejemplo de la aplicación de este decreto es la carta del delegado en Remedios al dueño del ingenio "Dolores". Gabriel Herrera-Diego G. Abreu, 24 de febrero de 1897. Los dos documentos están reproducidos en V. WeYLER, Mi mando en Cuba... II, Madrid, 1910, págs. 271-273.

(65) El vicepresidente de la Compañía respondió a los rebeldes que informaría de esa demanda a su gobierno "para que considerara el modo cómo tratan los insurrectos a los ciudadanos americanos que tienen negocios en Cuba, los cuales, porque no contribuímos con nuestro dinero a la insurrección, violando nuestras leyes, amenazan tomar venganza destruyendo nuestras propiedades". La carta de McCreary, vicepresidente de la Compañía, fechada el 25 de enero de 1897, AMAE Política 2.418. Era la respuesta a la que, desde el cuartel general del "ejército libertador", le había enviado al presidente de la Compañía el general en jele de la división de Santiago de Cuba el 29 de diciembre. "Todo lo que no sea fuente de recursos para este ejército libertador debe ser destruido". Se le exigían 30.000 pesos, que deberían entregarse al delegado cubano en Nueva York. Ese recibo debía remitirse al cuartel general. Las autoridades españolas prometieron proteger a la empresa ferroviaria. Tetuán-Taylor, 20 de marzo de 1897, ib. 2.418. 


\section{ABSTENCIÓN DE LAS REPÚBLICAS AMERICANAS}

Si los pueblos manifestaban simpatía hacia la independencia de Cuba, los gobiernos no prestaron apoyo a los que luchaban por ella. Se habían olvidado de sus propios héroes. La esperanza de Martí no se estaba cumpliendo. Había gobiernos abiertamente hostiles a los independentistas (66). La delegación cubana en Nueva York diseñó una estrategia para modificar esa conducta. Había que vencer presiones adversas y trabajar para lograr un acuerdo entre los políticos de la otra América y llegar así a una acción colectiva, resuelta y eficaz, que auxiliara a Cuba en guerra por su libertad (67). La inhibición de las repúblicas hispanoamericanas tenía varias causas: la apatía de sus dirigentes, las antipatías hacia Estados Unidos, que parecía proteger a los rebeldes, y las simpatías hacia España (68).

El gobierno de la República de Cuba se dirigía a todos los de América el 8 de agosto de 1896. Se afirmaba la existencia de un poder legítimo y se denunciaba los agravios económicos y políticos cometidos por España (68). La lucha por la independencia tenía ya 50 años. Todos los pueblos de América estaban interesados en restablecer la paz en la isla: se estaba quebrantando la prosperidad económica y se aventaba recelos contra España (69). Se apelaba a los buenos oficios de esos Estados soberanos, que tenían ahora la oportunidad de hacer oír su voz en asuntos internacionales, revalidando los principios a los que debían su existencia como naciones. Podían cooperar a conseguir una paz que a nadie humillara y respetara los derechos de todos (70).

(66) Ese era el caso argentino. Estrada-Nicolás de Cárdenas (Londres), 21 de agosto de 1897: [47] I, pág. 72.

(67) Estrada-Nicolás de Cárdenas y Chappotin (Londres) 3 de junio de 1896 [47], I, pág. 48. Esos gobiernos estaban sacrificando los derechos del pueblo cubano a las exigencias españolas. Estrada-Nicolás Domínguez Cowan (México), 6 de junio de 1896, ib. pág. 51.

(68) Ese era el dictamen del delegado cubano en Perú. Aristides AgüeroEstrada, Lima 22 de mayo de 1898 [47], 11, pág. 16.

(69) A este recuerdo histórico debieran ser sensibles los destinatarios del mensaje. Después de la independencia, aquellas naciones "ha(bía)n podido cultivar con su antigua metrópoli, sin desagrado ni indignidad, las relaciones materiales y mentales, que son siempre más fáciles entre los pueblos de la misma cepa y procedencia".

(70) "Al intervenir para que España reconozca la independencia de Cuba, poniendo término a la efusión de sangre y a la destrucción de propiedades, que depauperan y debilitan a una porción importante de la América Latina, afirmarán una vez más su adhesión al principio a que deben su independencia como estado y su derecho a ser oídas en un asunto internacional que tan de cerca toca al porvenir de la raza que las puebla y cuya representación llevan en el Nuevo Mundo". El objetivo de la mediación era acabar con la guerra "en condiciones que nos aseguran a nosotros nuestra soberanía y a Espana las compensaciones 
El presidente de Ecuador había escrito a la Reina Regente (71). Se pidió a Eloy Alfaro que interviniera ante los otros gobiernos: se reiteraba la oferta de la proclama del 8 de agosto y se le pedía que reconociera como beligerantes a los independentistas (72). Esta misión coincidía con las conversaciones no oficiales que Betances sostenía con agentes españoles o personas interesadas en llegar a una solución pactada. En aquellas semanas tenían los sublevados dificultades económicas y buscaban un empréstito de 200 millones de pesos (73).

El gobierno de la República de Cuba podría haber autorizado a Estrada para negociar la independencia a cambio de una indemnización de 100 millones de pesos. La oferta tenía un plazo: antes de iniciarse la nueva campaña tras las lluvias (74). Era el límite sancionado en la constitución que los sublevados se habían dado (75).

\section{LOS PROBLEMAS CON LOS EXTRANJEROS EN ULTRAMAR}

La situación se complicó durante el verano de 1896. Al memorándum, las conversaciones para llegar a una solución negociada las dificultades financieras de los insurgentes vinieron a sumarse algunos cambios en Puerto Rico. Los rebeldes cubanos confiaban que la insurrección en Filipinas les beneficiara, pero no tenían intención de ampliar su lucha a la otra Antilla española. Betances era un borinqueño inscrito en el partido revolucionario cubano. Siempre que podía incluía a su patria en la reclamación

que puedan hacerle menos penosa la pérdida territorial que de todos modos ha de sufrir". Manifiesto del gobierno provisional de la República de Cuba a los Repúblicas Hispanoamericanas, 8 de agosto de 1896: Correspondencia Diplomática... I [47], págs. XXIX-XXXII.

(71) Vid. la carta de Eloy Alfaro a la Reina Regente, fechada el 19 de diciembre de 1895, AMAE Política 2.417.

(72) Estrada-Eloy Alfaro, 29 de septiembre de 1896 [47], I, pág. 85. Se entregó por medio de L. Felipe Carbó, ministro plenipotenciario del'Ecuador en Washington.

(73) Estrada-Betances, 25 de septiembre de 1896 [47], I, pág. 82. Vid. también la correspondencia entre ambos, 2 de octubre de 1896, ib. pág. 86 y 6 de octubre, ib. pág. 87.

(74) "Como regla general estoy dispuesto a tratar sobre la base de la independencia absoluta de la Isla de Cuba y del pago de unos 100 millones de pesos, por vía de indemnización a España; entendiéndose que esto último ha de sér antes de iniciarse la campaña de la seca, porque después ni eso of receremos". EstRada-BETANCES, 13 de octubre de 1896 [47], I, pág. 87.

(75) Recordó Estrada a Betances que un tratado de paz con España, conforme al artículo 11 de la constitución, sólo podía firmarse si conducía "la independencia absoluta". Estrada-Betances, 10 de noviembre de 1886 [47] I, pág. 93. 
de la independencia para Cuba. Preparativos de laborantes puertorriqueños en Estados Unidos y en otras islas vecinas dieron la alarma (76). Existía un instrumento jurídico: la ley del 4 de julio de 1870 , que fijaba el carácter y las condiciones civiles y políticas de los extranjeros residentes en Ultramar. Según su artículo 28, la autoridad competente podía expulsar a quienes falsificaran su identidad (77).

Los emigrados a Puerto Rico acudían con prontitud a documentarse. Adquirían así garantías plenas para desarrollar sus actividades. El gobernador general se quejaba de esa traba legal que le impedía actuar contra los que conspiraban contra España (78).

Había llegado el momento de recordar la vigencia de la circular del 12 de febrero de 1892, en la que el ministerio de Estado advertía a los representantes de España que comunicasen a los gobiernos ante los que estaban acreditados que las autoridades españolas iban a expulsar de sus territorios de Ultramar a todo extranjero del que se sospechase que conspiraba o prestaba cualquier tipo de ayuda a la rebelión. Era una medida justa, de la que ni siquiera el secretario de Estado Blaine protestó en su Nota del 23 de febrero de ese año (79).

El ministerio de Estado había recordado en ocasiones anteriores que las autoridades de Ultramar, según los principios y prác-

(76) El capitán general informó al ministro de Ultramar el 24 de agosto de 1896. Se estaba explorando voluntades y se reclutaba adictos, con vistas a ganarse a la gente del campo. Entre los rebeldes había conocidos revolucionarios que habían sido expulsados de sus países. Los que eran periodistas se dedicaban a desacreditar a la administraciuón española.

(77) Ultramar, Ley fijando el carácter y la condición civil y política de los extranjeros en las provincias españolas de Ultramar: Colección legislativa de España 104, Madrid 1870, 25-31. "Los extranjeros traseúntes podrán residir en el punto en que elijan. Esto no obstante, cuando los residentes en un punto determinado pudieran por su número, procedencia u otras circunstancias poner en peligro las relaciones amistosas de España con otra nación, el Gobierno o la autoridad superior de la provincia podrá señalarles otro punto de residencia" (art. 20). "El emigrado que, no pudiendo identificar su persona, faltase a la verdad en relación con su nombre y circunstancias, podrá ser expulsado del territorio español por orden del Gobierno o del gobernador superior de la provincia. Igualmente podrá ser expulsado el que para identificar a su persona presentase documentos falsos o hiciese una falsa información. En este caso se procederá criminalmente y con arreglo a las leves contra los españoles que, de cualquier modo, hayan tomado parte en el delito" (art. 28).

(78) Pedía que se modificaran los artículos 20 y 28 de esa ley.

(79) Antes de responder sobre el criterio del gobierno, se quiso conocer el informe del ministerio de Estado para saber si las facultades que otorgaba la ley del 4 de julio de 1870 estaban delegadas en los gobernadores generales de Cuba, Puerto Rico y Filipinas. Real orden del ministro de Ultramar al ministro de Estado, 29 de septiembre de 1896, AMAE Política 2.414. 
ticas del derecho internacional, tenian facultades para expulsar a los extranjeros que atentaran contra la seguridad nacional. Era un deber de cortesía explicar al gobierno, a cuyos ciudadanos se aplicara la medida, las razones y causas, previendo que pudiera formularse alguna reclamación. Había que ser exquisitamente prudentes, pues la expulsión lesionaba contra un derecho individual, reservándola a aquellos casos en que fuera notorio el abuso contra la hospitalidad española. Un procedimiento correcto era avisar al cónsul de ese país, sin darle explicaciones (80).

\section{ESTADOS UNIDOS Y LAS REFORMAS EN CUBA}

Para los españoles era evidente que la insurrección cubana favorecía los intereses de Estados Unidos. Hemos visto cómo Salmerón lo subrayó ante Betances cuando le pidió que aceptaran la autonomía y no admitieran la intervención de extraños para obtener una independencia pactada. Desde el principio fue una preocupación el comportamiento de los cónsules norteamericanos en La Habana (81). Los cubanos presionaban en Washington para ganarse el apoyo de la administración. Había un lobby de congresistas, trabajados por Gonzalo de Quesada (82). Consiguió la delegación cubana en Nueva York que el Congreso reconociera como beligerantes a los cubanos (83). Con eso se admitía la

(80) El ministerio de Estado quería cuidar las buenas relaciones con los gobiernos amigos. Sabía que la puesta en marcha de las expulsiones podría generar tensiones y pensaba que debía proporcionar a los representantes diplomáticos en los países afectados por esas medidas todos los datos, que permitieran justificar el comportamiento de las autoridades. Con ese fin convenía que se remitiera al ministerio de Estado el expediente. Real orden del ministerio de Estado al de Ultramar, 14 de octubre de 1896, ib. 2.414. Se adjuntaba copia de la circular del 2 de febrero de 1892.

(81) El presidente Cleveland incluyó despachos de estos agentes consulares en su informe al Congreso acerca del progreso de la insurrección. Fueron traducidos y enviados a Madrid. Destacan en esa información algunos datos: la pérdida del valor adquisitivo de los salarios y el malestar que había generado, la guerra de tierra quemada, decretada por Máximo Gómez, el tratamiento humanitario que los dos contendientes daban a los prisioneros, el juicio sobre la actuación de Martínez Campos... Texto y traducción, AMAE Política 2.416.

(82) En virtud de un decreto del 21 de noviembre de 1895, Tomás Estrada nombró encargado de negocios en la capital norteamericana a Gonzalo de Quesada Aróstegui. Tenía 27 años. Era una persona muy cercana a José Martí. Jugaría un papel importante en todas las gestiones que condujeron a la Joint Resolution. Hay una biografía de Quesada, J. Llaveria, Correspondencia Diplomática... [47], V, págs. V-VII.

(83) Vid. Ph. S. Foner, La guerra hispano/cubana/americana y el nacimiento del imperialismo norteamericano, 1895-1902 1, Madrid, 1975, págs. 240-247. 
existencia de un estado de guerra en la Isla, que imponía a Estados Unidos una neutralidad absoluta. Votada el 28 de febrero de 1896, la resolución pedía al presidente Cleveland que of reciera «sus oficios amistosos al gobierno español para el reconocimiento de la independencia de Cuba» (84). Había que inutilizar sus efectos.

Iba a montarse una campaña para desacreditar a los rebeldes, a quienes se acusaba de pisotear los sentimientos humanitarios y no respetar la vida de las personas. Se subrayaba el contraste entre Cuba española y una Isla bajo el poder de los que entonces estaban alzados en armas (85). Aunque el ejecutivo norteamericano no estaba vinculado por las decisiones del Congreso, había motivos para preocuparse. El secretario de Estado lo comentó con Dupuy. Había que apresurar la llegada de la paz. Cleveland sería leal con España. Era contrario a la independencia, porque estaba persuadido, lo mismo que otros partidos y varios sectores de la sociedad cubana, de que los insurrectos no podían constituir una "nacionalidad sólida». Según las noticias en poder de Olney, España necesitaba mucho tiempo para poder contener la rebelión. Los insurgentes tampoco podrían conseguir sus objetivos a corto plazo. El resultado sería la destrucción de toda la riqueza de la isla.

Los intereses de Estados Unidos sufrían quebranto. Deseaban ayudar a España en la pacificación de Cuba. Prueba de su buena voluntad era la oposición de la administración a todo aquello que menoscabara la soberanía española. La comisión de investigación, creada en el Congreso, jamás podría trasladarse a Cuba, sin el consentimiento del gobierno de Madrid. Una política de reformas, no aceptadas por los independentistas, provocaría un cambio en la opinión norteamericana. Dejaría de otorgar su apoyo moral a los separatistas. Este distanciamiento de quienes

(84) Texto y comentario de esta resolución. Weyler [64], I, pág. 169.

(85) "Eso es Cuba insurrecta: el desborde del crimen en todas sus manifestaciones por los detritus de la sociedad antillana. En cambio, Cuba española es la mayoría; son los partidos políticos, son las Cámaras de Comercio, las sociedades industriales, las regionales, las organizaciones todas respetables, la mujer pura y blanca amenazada en su honor por la salvaje negrada, cuanto vive y late y alienta puro, noble y generosos eso es de España en Cuba". Los "beligerames": Las Novedade's (Nueva York, 19 de marzo de 1896) 1. Con esa misma orientación, Los crimene's del separatisme: Diario de la Marina, 31 de marzo de 1896, 1 y las fieras de la manigua: ib. 5 de abril, 1. 
los sostenían los conduciría a la derrota (86). Aún estaba en primer lugar el esfuerzo "pacificador" y la diplomacia se ponía subordinadamente a su servicio. En esas fechas Maceo había regresado a Occidente. Era un desafío a la pretensión española de tener arrinconadas la rebelión y de controlar los movimientos de las partidas.

Llegaban hasta Cleveland presiones desde todos los ámbitos de la sociedad (87). España hizo a Estados Unidos responsable de la situación denunciada por Olney. Los insurrectos tenían en su territorio la base de "recursos materiales y morales", que les alentaban con la esperanza de recibir uotros próximos todavía más eficaces». Era ésta la principal causa de que los esfuerzos españoles no hubieran logrado sofocar la rebelión, condición para poner en vigor "amplias y liberales reformas políticas».

Sabían los independentistas que por sí solos, y mucho menos por las armas, no podían aspirar a la victoria. No consolidarían sus afanes. No llegarían a poner en peligro la soberanía de España. De Washington se esperaba únicamente esta cooperación: quitar a los revolucionarios la expectativa de que los norteamericanos fueran solidarios con ellos. España estaba dispuesta a poner en marcha y extender esas mejoras en el regimen político y administrativo de la Isla, una vez llegada la paz. Con todos los defectos que se achacara a la administración española, nadie podría negar que se había producido en Cuba un incremento notable de la riqueza (88).

\section{LOS BUENOS OFICIOS DE WASHINGTON}

Había un clima propicio a la mediación. En el mes de abril, el presidente de la República Dominicana propuso a Cleveland como

(86) Todos estos comentarios se hallan en la conversación entre Olney y Dupuy, celebrada el 20 de mayo de 1896, durante la visita habitual que celebraba el secretario de Estado con los diplomáticos destinados en Washington. Era la tercera vez que, de manera no oficial, Olney hablaba de estos aspectos con el representante español. Todo quedaba pendiente del curso de las operaciones militares. Había que vencer antes de la estación de las lluvias. En caso contrario, se temía que los rebeldes pudieran proseguir su guerra de destrucción al llegar de nuevo la seca. Cifra. Dupuy-Tetuán, 20 de marzo de 1896, AMAE Política 2.417 .

(87) La Iglesia católica estaba realizando gestiones reservadas ante el presidente Cleveland. Quesada-Estrada, 24 de marzo de 1896: [47], V, págs. 46-52.

(88) Cifra. Tetuán-Dupuy, 22 de marzo de 1897, ib. 2.417. 
árbitro para alcanzar la paz en Cuba. Se crearía una Comisión Internacional de Arbitraje, con tres naciones europeas, elegidas por España, y otras tres americanas a propuesta del presidente de Estados Unidos. Estaría presidida por el jefe del Estado de la nación donde tuviera su sede o podría ser elegido por los seis árbitros. Los países representados correrían con los gastos. España y los cubanos deberían aceptar las bases de arreglo propuestas (89).

Las preocupaciones de Olney se consignaron en una Nota entregada a Dupuy el 4 de abril de $1896(90)$. La inquietud del presidente y su deseo de una pronta y permanente pacificación inspiraban la oferta de sostener cualquier plan que garantizara ese resultado y fuera compatible con los «justos derechos y razonables aspiraciones de todos los interesados». No se había cumplido las expectativas. Los rebeldes dominaban una parte de la Isla más extensa que en ocasiones anteriores. La ausencia de los requisitos exigibles había impedido que se reconociera a los separatistas como beligerantes. En algunos territorios de la Isla había sido destruida la autoridad de España. Pese a todos los combates y a los logros alcanzados, la insurrección proseguiría, a la vista de la organización y de las motivaciones de quienes se habían alzado en armas contra España. Se recordaba la declaración de sus Cámaras en 1877, cuando cayó prisionero el presidente de la denominada República de Cuba.

La falta de control sobre la totalidad del territorio provocaba una "guerra sistemática contra la industria de la Isla y contra los medios de ejercerla». El producto de la economía cubana había descendido un $20 \%$ de su rendimiento habitual. La situación se iba deteriorando. Una prudente previsión era «la completa devastación de la Isla, el completo aniquilamiento de sus industrias» y

(89) "Nadie mejor que el ilustrado presidente de los Estados Unidos de Norteamérica para hacer oír esos acentos de pacificación, que han de resonar simpáticamente en todo el orbe civilizado y cristiano. Nadie más autorizado que el presidente Cleveland, que tan altamente ha acreditado la moderación de su carácter, su respeto al derecho de los demás pueblos, para dirigirse a España amistosa y persuasivamente, para conseguir de ella y persuadir a los cubanos a que se sometan a un jurado internacional, de juicio imparcial, sobre sus derechos respectivos, sus agravios y aspiraciones; en la seguridad que la más estricta y desinteresada justicia habrá de inspirar y realizar el concierto de todos los intereses legitimos y atendibles". Ulises Heureaux, Santo Domingo 11 de abril de 1896. Texto en Correspondencia Diplomárica... IV [48], págs. 155-157.

(90) Documenios presentados a las Cortes por el Excrno. Sr. Ministro de Estado, duque de Almodóvar del Río, Madrid 1898, págs. 3-8. 
el empobrecimiento de todos aquellos habitantes que (fueran) bastante imprudentes e infortunados para no poder escapar de ella».

Aleccionada por la experiencia de la guerra de los Diez años, España quiso aplastar la sublevación en sus comienzos. Concentró tropas suficientes y puso a su mando al general más hábil de su ejército. Hombre de Estado, que of recía a los insurgentes la garantía de que sus demandas se atendieran con ánimo liberal. Así se enjuiciaba a Martínez Campos como militar y político. Weyler, en cambio, presagiaba que el final sería el abandono de Cuba por España «a la heterogénea combinación de elementos y razas que actualmente se halla(ba)n en armas contra ella». Al producirse esta situación, se desencadenaría una horrible guerra de razas, una vez roto el lazo que las unía. La paz no estaría segura ni con la posibilidad de crear dos repúblicas, diferenciadas racialmente, porque no podrían coexistir sin tensiones.

Tanta destrucción y amenaza estaban sucediendo junto a las costas de Estados Unidos. No había injerencia en un asunto que "era de la mayor importancia para el pueblo" norteamericano, una nación cristiana y civilizada, que no podía contemplar indiferente los horrores de la guerra. Personas honestas habían insistido «en que la intervención para terminar este conflicto era (un) deber inmediato e imperativo para Washington. El objeto de la Nota no era la intervención. En ella se inquiría si podía hallarse un arreglo a los disturbios y desórdenes, "que impidiera todo pensamiento de intervención, haciéndola innecesaria» (91).

Según Olney la propuesta era aceptable para las dos partes, dadas las intenciones y la conducta que con ambas había mantenido Estados Unidos. España debía unir reformas políticas y acción militar buscando suprimir cualquier motivo de queja por parte de aquéllos que se habían levantado contra su autoridad. Las medidas políticas eran exclusiva competencia de Madrid, pero la administración Cleveland podría recomendar su aceptación si lo juzgase oportuno, utilizando con ese fin toda su influencia ante los sublevados. En todo caso, de esa forma, se

(91) Olney formulaba así su propuesta: "Lo que los Estados Unidos descan hacer, si se les permite indicar el camino, es cooperar con España para la inmediata pacificación de la Isla, bajo una base que, dejando a España sus derechos de soberanía, consiga para el pueblo de la Isla todos los derechos y poderes del gobierno propio local que pueda razonablemente pedir. Para este fin, los Estados Unidos of recen y usarán sus buenos oficios en el tiempo y manera que se considere más prudentes". 
minaba el apoyo moral y económico que podría dar a los separatistas la opinión norteamericana (92).

Claro y preciso en su estilo y transparente en sus propósitos: así enjuiciaba Dupuy de Lome la Nota del secretario de Estado. Si atribuía a la insurrección mayor fuerza que la que tenía, se debía a la presión que la prensa y el Congreso ejercían sobre la opinión. Había que subrayar, sin embargo, el reconocimiento de la soberanía española en Cuba (93), la conclusión era alentadora: Olney y Cleveland eran amigos y se comportaban lealmente. La agitación en las dos Cámaras del Congreso y en la prensa era un movimiento superficial, aunque extendido. Se presionaba al Presidente, que no podía hacer más en favor de España. Había probado que era una persona de valor.

Esas impresiones se confirman el 9 de abril. En una conferencia con el ministro de España en Washington, Olney declaró que el gobierno de Madrid era totalmente libre para determinar el contenido de las reformas y la ocasión para iniciarlas. Era deseable que se adelantaran todo lo posible, porque con ello se ayudaba al Presidente y a su administración, que estaban resistiendo a una opinión extraviada, que reclamaba la intervención en Cuba (94). Olney se equivocaba respecto a las intenciones de los separatistas. Con 24 positivos frente a 27 negativos en la votación sobre el reconocimiento de beligerancia, Estrada estaba convencido de que la mediación sería un fracaso. Los revolucionarios

(92) Olney concluia reiterando los sentimientos de amistad y alertando para que se evitara ver en la Nota oscuros proyectos, porque "sería un error grande y lamentable". Un arreglo rápido no sería permanente si no se fundaba en la verdad y la justicia. Texto inglés de esta Nota del 4 de abril: Report of the secretary of State (Richard Olney) of the United States to the President for the vear 1896, Washington 1896, 20-28. Dupuy respondió el 8 de abril. Agradecia los sentimientos de amistad y resaltaba la importancia de su contenido. Pasaba copia a su gobierno. Así lo hizo a través de Antonio Pla, agregado a la legación, que entregaría la Nota al duque de Tetuán. 58 Dupuy-Tetuán, 10 de abril de 1896 , AMAE Política 2.416

(93) Esta manifestación era de mayor valor, si se consideraba que la información sobre la guerra en la Isla era bastante exacta. “...al lado de sus errores, que son los mismos que los de toda la prensa europea y americana, hay manifestaciones tan explicitas de reconocimiento a la soberania de España, declaraciones tan categóricas y tan respetuosas de que no se intenta intervenir ni mezclarse en nuestros asuntos interiores, conocimiento tan exacto de lo que son los insurrectos $\checkmark$ sus apreciaciones tan verdaderas de lo que sería la lsla, si a ellos se viera entregada, y seguridades tan francas de que los Estados Unidos no abrigan intenciones ambiciosas, gze considero muv satisfactorio el escrito de Mr. Olnev". Dupuy se alegraba de haber recibido este documento.

(94) Dupuy-Tetuán, 10 de abril de 1896, AMAE Política 2.416, reproducido en Documemlos presemades... |90], págs. 2-3, donde aparece fechado el 8 de abril. 
no aceptaban más que la independencia (95). España apenas podría conceder la autonomía que se sugería en la Nota (96). Era un reto para el gobierno conservador. Discutida en consejo de ministros y con la aprobación de Cánovas, se le daba respuesta el 22 de mayo (97). Se había cuidado todos los detalles. Antes de contestar, se había querido dejar, en documento solemne, constancia de la postura de España, para que fuera evidente la independencia con la que actuaba. En el discurso de la Corona se había anunciado los amplios y liberales propósitos del ministerio (98).

Estados Unidos no podía reconocer beligerancia a los insurgentes (99). Deberes de soberanía, aceptada en la Nota del 4 de abril, imponian la necesidad de someter a los separatistas, de manera que no sufrieran menoscabo la autoridad y el honor de las armas españolas. Con ello se subrayaba que la Nota descartaba totalmente la hipótesis de una intervención. La presencia de españoles era un factor de equilibrio racial en la isla. Sin ella, lo previsible sería la guerra civil y se produciría una situación social inestable. Antes de la insurrección, Cuba gozaba de prosperidad económica (100) y se

(95) Estrada-Aristides Agüero (Santiago de Chile), 29 de abril de 1896: Correspondencia Diplomática... I [48], pág. 30. Estrada-Ulpiano Delluadé (Cap Haïtien), 2 de mayo, ib. pág. 34 .

(96) "Creo que, en el supuesto de ser aceptada la mediación, no se llegará a ningún acuerdo. Los revolucionarios no han de admitir ningún trato que no arranque del reconocimiento explícito de la independencia; y el gobierno español no llegará ni aun a la concesión de la autonomía, inaceptable para nosotros por amplia que fuera; pero como Mr. Cleveland propone su mediación para algo y fundándose en los graves perjuicios que están sufriendo los intereses de los ciudadanos americanos, puede considerarse que su actual iniciativa no se detendrá ante el fracaso de las gestiones que ahora se promuevan para terminar el conflicto, sino que tal vez (sea) un paso que, al fin, redunde en medidas ventajosas para la revolución cubana". Estrada-Joaquín Alsina, representante en San José de Costa Rica, 18 de abril de 1896: Correspondencia diplomática...I [47], pág. 22. EstradaRamón Valdés García (Montevideo), 22 de abril, ib. pág. 27.

(97) Reservado, Tetuán-Dupuy, 22 de mayo de 1896, AMAE Política 2.416 y Documentos presentados... [90], págs. 8-13.

(98) La guerra había frenado el proceso para equiparar los derechos políticos de antillanos y peninsulares. Anunciar ese firme propósito de reformas en el discurso de la Corona era probar que se harían, con el acuerdo de todos los partidos presentes en las Cortes y no por presión ajena.

(99) Esta primera constatación era importante porque apelaba a los principios y usos del derecho internacional. Conforme a ellos, no se cumplía ninguno de los requisitos previstos para otorgar la beligerancia. Era el mejor modo de rebatir el alcance y la fuerza de los sublevados. Su campaña militar se reducía a la comisión de "actos vandálicos y de destrucción".

(100) El triunfo de la insurrección abriría un periodo de anarquía, que afectaría gravemente a todos los intereses, poniéndolos en peligro de desaparecer. 
regia por uno de los sistemas políticos "más liberales de la tierra». Un ejemplo era la libertad de prensa.

Con la paz, se llevaría a cabo cualquier reforma que beneficiase a Cuba, atendiese las justas reclamaciones de sus habitantes y salvara la soberanía de España. Hasta el momento, no iba por detrás de las sugerencias de Washington la política del gobierno conservador. Que los rebeldes fueran contrarios a la mediación demostraba su desconfianza hacia Estados Unidos, a quienes atribuian la intención de apoderarse de la isla. España, si no aceptaba ese ofrecimiento, tenía razones de soberanía y de legitimidad: no podría negociar de igual a igual con unos "súbditos rebeldes». La cooperación que se solicitaba se concretaba en estas demandas: prohibir las expediciones filibusteras y controlar y reprimir las actividades de emigrados cubanos en Estados Unidos que violaban el derecho de gentes. Para ilustrar a la opinión y ayudar a la administración a resistir las presiones, Madrid proporcionaría todas las informaciones necesarias y publicaria sus intenciones y proyectos acerca del porvenir de Cuba. Cuando se convencieran de que no iban a recibir apoyos decisivos, aquellos separatistas que no buscaran la ruina total de su patria arrojarían las armas. Entretanto, España continuaría "la justa defensa de sus derechos... de su deber y su honra", esforzándose por vencer pronto y sin temor a los mayores sacrificios (101).

Para no admitir la propuesta de mediación, eludiendo cualquier responsabilidad, se señalaba que los rebeldes cubanos la habían rechazado ya a través de su Junta en Nueva York. Eran falaces las declaraciones de la administración Cleveland y pensaban los insurgentes que Estados Unidos tenía el designio de apoderarse de Cuba. La mejor cooperación que España podía

(101) Con estas instrucciones debía elaborar el ministro de España en Washington su respuesta a Olney. Copia del documento: AMAE Política 2.416. Anexo a 151 Dupuy-Tetuán, 11 de junio de 1896. Texto de la respuesta entregada a Olney ese día, pero fechada el 4 de junio, Documenlos presentados... [90], pág. 14. La respuesta entregada a Olney resumía la recibida desde Madrid. Tenía el mismo estilo que el texto del duque de Tetuán: aceptar todo lo que afirmaba Olney, pero integrándolo como argumento en la defensa de la política seguida en Cuba. Si no se hacía justicia al gobierno español, se debía al extravío de la opinión por culpa de falsas informaciones. El pueblo aceptaba todos los sacrificios necesarios. No se buscaba solo una solución militar. Se iba a ampliar y mejorar las medidas aprobadas por el ministerio liberal el 15 de marzo de 1896. Actuaría el gobierno de Madrid "con gran generosidad de miras". 
recibir era la represión de las expediciones desde territorio norteamericano (102).

Los países de la otra América estaban pendientes de lo que se decidiera en Washington. Todos sus gobiernos relativizaron el alcance de lo que había votado el Congreso. Carecía de eficacia sin la aprobación del presidente. A los cubanos preocupaba más la perspectiva de la anexión que la falta de auxilio por parte de los norteamericanos (103). Era la misma opinión que sostenía Dupuy de Lome. Tras la votación del Congreso, asunto concluido. Los líderes de las dos Cámaras habían tomado la decisión de no volver a ocuparse de la cuestión cubana. Cleveland afirmó ante los senadores Sherman, Lodge y Gray, del Comité de Relaciones Exteriores, que no tenía justificación el inmiscuirse en los problemas de la isla (104).

Tuvo lugar entonces la proclama de Cleveland renovando las advertencias que un año antes había dirigido a quienes quebrantaran las leyes de neutralidad, que contenían un amplio elenco de prohibiciones respecto a las diferentes formas de cooperación con los independentistas. Con estas medidas y con la Nota de Olney se frenó el memorándum, según vimos más arriba. El ministerio de Estado, sin embargo, no quedó tranquilo, porque sospechaba que se estaba preparando así la intervención en Cuba.

\section{Mensaje De Cleveland al Congreso}

El informe anual del Presidente al Congreso era una buena oportunidad para conocer qué criterios tenía el gobierno y cuáles

(102) Quiso Olney incluir esta respuesta en su informe anual al Presidente. Pidió la autorización. Cifra. Dupuy-Tetuán, 10 de abril de 1897. Se aceptó con la condición de que España pudiera publicar la declaración de Julio Sanguily. Cifra. Tetuán-Dupuy, 10 de abril, AMAE Política 2.416. Sobre este caso, vid. Robles [30], págs. 274-279.

(103) "Aquí (en Chile) se sigue con mucha atención la cuestión de la beligerancia yankee. Desgraciadamente nadie quiere moverse antes que el coloso Sam. Ahora creen que lo hecho por las Cámaras es puramente platónico, puesto que Cleveland queda libre de hacer positivo o negativo el ruego del pueblo. Hay la opinión de que los Estados Unidos desean anexionarnos más que favorecernos...". Arístides Agüero-Estrada, 26 de abril de 896: Correspondencia Diplomática... |47] Il, 43 .

(104) A eso se sumaba un descenso en la simpatía hacia los separatistas dentro de la opinión. Sólo un incidente desagradable podria invertir esa tendencia. Cifra. Dupuy-Tetuán, 31 de enero de 1896, AMAE Politica 2.417. 
cran sus planes (105). Según Cleveland, la pacificación no progresaba. Los negocios continuaban perturbados por la guerra. Cada día era más firme por parte de España la resolución de vencer. La insurrección estaba decidida a combatir hasta sucumbir, aunque no había creado aquellas condiciones que permitieran su reconocimiento internacional. Fuera de las grandes ciudades y de sus zonas próximas reinaba la anarquía. La lucha tenía por escenario las áreas rurales. Por su naturaleza y por la estrategia de los insurgentes, no había batallas de importancia. De ese modo España no terminaría en un plazo corto con el conflicto. Las partidas podrían sobrevivir con escasos medios materiales, dados el clima y los frutos que la tierra les ofrecía para poder mantenerse en la manigua. Se prolongaba el desorden y se encendían las pasiones. Era una guerra civil. El gobierno español terminó adoptando la táctica de los revolucionarios: destruir todo lo que pudiera beneficiar al enemigo. Se estaba aniquilando de este modo toda la riqueza industrial. Se corría el riesgo de acabar en poco tiempo con toda la producción azucarera. "La ruina de un país contiguo, uno de los más fértiles y encantadores del globo, por su naturaleza llamaría la atención del gobierno y del pueblo de los Estados Unidos en cualesquiera circunstancias".

Después de España, era la nación que tenía más intereses en Cuba. Sus inversiones en la Isla alcanzaban la cifra de cincuenta millones de pesos fuertes. Se concentraban en la minería, ferrocarriles, plantaciones y otros negocios. El comercio había pasado de sesenta y cuatro millones de pesos fuertes en 1889 a ciento trece millones en 1893 y unos noventa y seis millones en 1894. Por medio de colectas, proclamas, meetings, compras y embarque de armas, los cubanos residentes en Estados Unidos violaban el espíritu de las instituciones y el texto de las leyes. Algunos habían

(105) Message to the Congres of Unites States... Washington 1896, págs. 3-10. El texto llegó a manos de Dupuy cuatro horas antes de que fuera entregado al Congreso. Ese dia, 9 de diciembre de 1896, Dupuy envió tres cifras al ministro de Estado. En ellas le resumía las primeras reacciones, muy favorables en los círculos conservadores. Habian decepcionado a los laborantes y la Junta de Nueva York.

La prensa habia aprobado la postura de Cleveland, y la presentaba así a sus lectores: Estados Unidos sólo intervendría en el caso de que España no pudiera sofocar la rebelión. Las mismas impresiones se recogían en círculos políticos y diplomáticos de Francia. Los partidarios de la independencia se mostraban muy contrariados. Cifra. Duque de Mandas-Tetuán, 10 de diciembre de 1896. La reacción en Inglaterra la transmitia el embajador en Londres. 1.011 Conde Casa Valencia-Tetuán, 3 de diciembre; 1.017, 7 de diciembre y 1.031, 9 de diciembre. AMAE Politica 2.416. 
obtenido la nacionalidad norteamericana (106). Como consecuencia de ello, el gobierno se veía obligado constantemente a proteger a ciudadanos norteamericanos, a reclamar indemnizaciones por pérdidas de bienes, que se elevaban a muchos millones de pesos fuertes, a pedir disculpas por el comportamiento de algunos de sus funcionarios y exigir explicaciones por la conducta de sus colegas españoles. La línea de costa que debía vigilarse era muy extensa y eso permitía la salida de expediciones.

Todas estas razones parecían avalar una intervención en Cuba, que podía consistir en otorgar la beligerancia a los insurgentes, reconocer su independencia, comprar la Isla o intervenir directamente, a riesgo de una guerra con España. Los partidarios de esta última salida sabían que la contienda sería breve, poco costosa y su resultado no era dudoso. Cada una de estas propuestas era inaceptable, difícil e inoportuna, contraria al derecho internacional y transgresora de pactos bilaterales. Un arreglo implicaba el concurso de España, que no se mostraba dispuesta a discutir un asunto interno. La más abominable de todas las soluciones era la guerra, porque Estados Unidos había elegido, en sus relaciones con otros estados, el derecho excluyendo la violencia. Nada podía justificar la ruptura de la paz. Había territorios disponibles para calmar a los ambiciosos y expansionistas. La paciencia tranquila, con la que estaba actuando la administración era una prueba del gran respeto y de la consideración del pueblo norteamericano hacia una nación amiga (107). Estados Unidos no había cerrado los ojos ante agravios que sufrían los cubanos y que la propia Reina Regente había admitido y habían sido expuestos en las Cortes por los más patrióticos e ilustres hombres de Estado, sin distinción de partidos. Las reformas aprobadas y en marcha querían servir de remedio.

(106) "Los insurrectos están indudablemente alentados y sostenidos por la mucha simpatía que el pueblo de este pais siente siempre e instintivamente por todo esfuerzo para obtener un gobierno mejor y más libre y, cuando se trata de los elementos más aventureros e inquietos de nuestra población, conduce en demasiados casos a una participación activa y personal en la lucha".

(107) "No olvidan en verdad (los Estados Unidos) su relación con el descubrimiento del Hemisferio Occidental, ni menosprecian las grandes cualidades del pueblo español, ni dejan de reconocer en toda su plenitud su espléndido patriotismo y su caballeresca veneración del honor nacional. Con asombro y admiración contemplan la animosa decisión con que grandes cuerpos de ejército cruzan miles y miles de millas del océano y la enorme deuda que se acumula para que la costosa posesión de la joya de las Antillas ocupe aún un sitio en la Corona española". 
La autonomía quitaba cualquier pretexto razonable a los independentistas (108). La deseaba la mayoría y con ella se acabaría una contienda, que estaba dejando un territorio desolado para el que lograra vencer. España no vería rebajado su honor. Los cubanos podrían con el autogobierno dirigir su progreso y el crecimiento de su riqueza, demostrando su capacidad política. Cleveland aceptaba que la sumisión fuera la condición previa para la autonomía. Había, sin embargo, un obstáculo: dos años de guerra habían estabilizado la revolución. No podían aplazarse las reformas hasta que se produjera una entrega de las armas a discreción. Esta afirmación del Presidente era crucial. Todos colocaban la frontera de lo innegociable justamente en el límite en que podría hallarse una zona de encuentro. Es siempre la parte más débil la que tiene motivos para justificar sus recelos. La Nota del 4 de abril demostraba que Estados Unidos no desconfiaba de la sinceridad de los propósitos de España. Cleveland, a diferencia de Olney, creía que la propuesta de mediación no había sido mal recibida y tampoco podía dudarse de que los insurgentes cubanos la aceptaran. Ninguna de las dos partes podía dejar de calibrar la importancia de una acción rápida. La administración estaba a disposición de los contendientes (109), dejando claro que todo era viable, salvo la adquisición de la Isla o la intervención de otra potencia (110)

La premura de una solución permanente y estable al desorden en Cuba se convertía asimismo en una advertencia (111). Estados Unidos estaba dispuesto a salvar las exigencias de su interés y de

(108) "Parece que si España ofreciese a Cuba una verdadera autonomía, medida de gobierno interior y que, al mismo tiempo, que preservase la soberania de España satisficiese todas las exigencias racionales de sus súbditos españoles, no habría motivo justificado para que la pacificción de la Isla no pudiese efectuarse sobre esta base".

(109) "Los oficios amistosos de los Estados Unidos, tanto en la forma arriba descrita, como en cualquier otro camino compatible con nuestra Constitución y nuestras leves, estarán siempre a la disposición de cualquiera de las dos partes".

(110) Posiblemente Cleveland quería salir al paso de cualquier intento de Alemania que tuviera por objetivo adquirir Cuba, violando así uno de los supuestos de la "redistribución colonial", que reservaba, a beneficio de Estados Unidos, toda modificación en el estatuto de un territorio en aquella zona. Hay que esperar el estudio de la documentación alemana, sobre la que viene trabajando Luis Alvarez. Gutiérrez.

(111) "... al mismo tiempo que descamos conceder todo el respeto a la soberania de España, no podemos ver el conflicto pendiente en todas sus fases y tener intimas e inevitables relaciones con él y sus resultados posibles, sin conside. rar que, por el curso de los acontecimientos, podemos ser llevados a un estado tan extraño y sin precedentes que tengamos que poner un límite a nuestra 
su honor. Lo haría en su momento (112). Para el gobierno de Cánovas el tono y el contenido del Mensaje eran satisfactorios. Se sintió respaldado por las reacciones en las capitales europeas y por las valoraciones de la prensa americana (113). Para la emigración cubana fue decepcionante la actitud del presidente Cleveland. Su única esperanza era el plazo que veladamente imponía a España para sofocar la rebelión. Sabían en Washington que el ejército español no podría vencer (114). El gobierno de la República de Cuba se felicitó por la intención que Cleveland había expresado de intervenir de forma amistosa para frenar el conflicto (115).

Había pronosticado Quesada que el mensaje no sería hostil a los cubanos. Nada iba a ser determinante y el trabajo debía continuar hasta ganar el favor de los congresistas y lograr que se aprobara una declaración de independencia. Se precisaban cincuenta millones de pesos. Call esperaba conseguir ese empréstito en Londres (116).

Perseverar en los intentos de atraerse a un grupo de congre-

paciente espera de que España ponga término a la contienda sola y por sus propios medios, o con nuestra amistosa cooperación".

"Cuando la incapacidad de España de dominar la insurrección llegue a ser manifiesta y esté demostrado que su soberanía se extingue en Cuba para todos los fines de su existencia legítima, y cuando un esfuerzo desesperado para su restablecimiento degenere en una lucha que no tenga más objeto que el inútil sacrificio de vidas humanas y la total destrucción de lo mismo que es objeto del conflicto, se presentará una ocasión en que nuestras obligaciones respecto a la soberania de España estarán pospuestas a obligaciones más elevadas, que no podemos casi vacilar en reconocer y en cumplir".

(112) “... he juzgado que no es inconveniente recordar al Congreso que puede llegar un tiempo en que una politica y un cuidado de nuestros intereses, tanto como un respeto a los intereses de otras naciones y de sus ciudadanos, unidos a consideraciones de humanidad y un deseo de ver a un país rico y fértil, íntimamente unido con nosotros, salvado de una devastación completa, obliguen a nuestro gobierno a una acción tal que favorezca a los intereses así comprometidos y al mismo tiempo ofrezca a Cuba y a sus habitantes una oportunidad para gozar de los beneficios de la paz".

(113) Se ordenó al ministro de España que manifestara al secretario de Estado estos sentimientos de Cánovas y su gobierno. Cifra. Tetuán-Dupuy, 10 de diciembre de 1896, AMAE Política 2.416.

(114) Díaz Albertini, delegado de la Junta en Washington, había declarado a la prensa que el Mensaje era justo y merecía la aprobación completa de los independentistas. R. Díaz-Estrada 7 de diciembre de 1896: Correspondencia Diplomática... V [47], V, 12. No era ese el juicio de Gonzalo Quesada. "En cuanto a nosotros, (el mensaje) fue negativo - como su tenor general-, porque no of recía una solución terminante". Quesada-Estrada, 10 de febrero de 1896 [17], V, pág. 95 .

(115) Vid. el acta de sesión del Consejo de Gobierno, el 5 de enero de 1897: Correspondencia Diplomática.. I [47], págs. XXVIII-XXIX.

(116) "... si hay dinero, el reconocimiento de la independencia es un hecho antes del 15 de enero". Quesada-Estrada, 6 de diciembre de 1896, ib. [47], V, pág. 83. Más demandas de dinero: Quesada-Estrada, 16 de diciembre, ib. pág. 86. 
sistas era una sugerencia acertada. El 9 de diciembre se presentaba la proposición de Camerón, senador por Pennsylvania: Estados Unidos reconocia la independencia de Cuba y of recía sus buenos oficios para concluir la guerra. Ese mismo día la propuesta de Mills, senador por Texas, iba más lejos: Estados Unidos debia posesionarse de la Isla hasta que sus habitantes pudieran formar un gobierno y contar con fuerzas militares suficientes para repeler una invasión. Call, senador por Florida, pedía que se reconociera al Gobierno de la República de Cuba como un poder soberano $e$ independiente, con todas sus prerrogativas. Cullon, senador por Illinois, afirmaba el 10 de diciembre que el final de la presencia española en las islas del crucero del Golfo de México y la extinción de su dominio sobre ellas era una condición imprescindible para el bienestar de aquellas poblaciones y para la seguridad de Estados Unidos. Quesada creía que había que sostener la proposición Cameron. Intervino entonces Olney. Sus esfuerzos fueron vanos. El comité de relaciones exteriores del Senado la aprobó. Se planteaba un problema constitucional, cuya gravedad no soslayó el secretario de Estado (117).

Con un problema constitucional y pendientes otros asuntos, la cuestión cubana quedaría aplazada para después del 5 de marzo de 1897, cuando McKinley inauguró su presidencia (118). Las perspectivas no eran buenas para cubanos y españoles. Podía haber llegado la hora de los anexionistas (119). La guerra dejaba de ser un conflicto colonial con una metrópoli residual para transformarse en una pieza dentro del tablero de un imperio emergente.

(117) El 19 de diciembre afirmó Olney que esa proposición era un abuso de poder, porgue declarar la independencia y la beligerancia eran atribuciones del ejecutivo. Por otro lado, si Olney hubiera seguido por ese camino, podría haber dado lugar al impechment, porque Cleveland habria cometido desacato al Congreso.

(118) La proposición Cameron podría ser aprobada por el pleno del Senado antes del 15 de lebrero. Quesada-Estrada, 10 de Tebrero de 1897: Correspondencia Diplomática... V |47]|, págs. 95-97.

Sobre la actitud de la nueva administración, vid. H. Portrlt.-VII.A, Historia de Cuba en sus relaciones con los Estados Unidos y España, Miami 1961, III, págs. 268-366. Foni:R |83], págs. 267-293.

(119) La plataforma politica del partido republicano vencedor en las elecciones presidenciales, lue redactada por Foraker y Lodge, ambos partidarios de la anexión de Cuba.

"Era de esperar que (la política de McKinlev) se concretaría en una creciente presión sobre España para que abandonase Cuba, con un acercamiento a Inglaterra que garantizase a no interferencia de otras naciones en la cuestión y una actitud destinada a granjearse las simpatias y la gratitud de los cubanos para que cooperasen y no se opusiesen al cambio de dueño". PoRTELL-VII.A Idem, pág. 274. 